\title{
Penambahan Sari Kurma sebagai Substrat Antibakteri pada Minuman Whey Fermentasi
}

Addition of Date Juice as an Antibacterial Substrate in Fermented Whey Drinks

\author{
J. K. Negara ${ }^{*}$, M. Arifin ${ }^{2}$, E. Taufik ${ }^{2}$, \& T. Suryati \\ ${ }^{1}$ Program Megister Ilmu Produksi dan Teknologi Peternakan, Fakultas Peternakan, IPB University \\ ${ }^{2}$ Departemen Ilmu Produksi dan Teknologi Peternakan, Fakultas Peternakan, IPB University \\ Jl. Agatis, Kampus IPB Darmaga Bogor 16680, Indonesia \\ *Corresponding author: juliankn77@gmail.com \\ (Received 11-12-2020; Revised 15-01-2021; Accepted 28-01-2021)
}

\begin{abstract}
Whey from cheese is still underutilized in Indonesia which has the potential to cause environmental pollution. One alternative to whey processing is to make a fermented whey drink with the addition of date palm juice as a mixture. Dates juice is expected to provide additional nutrition for lactic acid bacteria (LAB) in the fermentation process. The purpose of this study was to determine the antibacterial properties of whey fermented beverage products with the addition of date juice. The study was conducted using a randomized block design (RBD) with six groups of sampling treatment with $\mathrm{P0}$; $0 \%$ as a control (whey: date juice 100: 0 v / v), P2; 10\% (90: $10 \mathrm{v} / \mathrm{v}), \mathrm{P} 2 ; 15 \%(85: 15 \mathrm{v} / \mathrm{v})$ and P3; 20\% (80: $20 \mathrm{v} / \mathrm{v})$. The results of this study indicate that the fermented whey drink with the addition of date juice fermented with the bacteria Lactobacillus fermentum B111K (L. fermentum) for 24 hours has been shown to have a higher antibacterial ability at the level of $20 \%$ compared to controls who were not given additional date juice.
\end{abstract}

Keywords: lactic acid bacteria (LAB), antibacterial, L. fermentum, whey fermentation, date palm juice

\begin{abstract}
ABSTRAK
Whey dari keju masih kurang dimanfaatkan di Indonesia yang berpotensi menimbulkan pencemaran lingkungan. Salah satu alternatif pengolahan whey adalah dengan membuat minuman whey yang difermentasi dengan tambahan sari kurma sebagai campuran. sari kurma diharapkan dapat memberikan nutrisi tambahan bagi bakteri asam laktat (BAL) dalam proses fermentasi. Tujuan penelitian ini adalah untuk mengetahui sifat antibakteri produk minuman fermentasi whey dengan penambahan sari kurma. Penelitian dilakukan dengan menggunakan Rancangan Acak Kelompok (RAK) dengan enam kelompok perlakuan pengambilan sampel dengan P0; 0\% sebagai kontrol (whey: jus kurma 100: 0 v / v), P2; 10\% (90: $10 \mathrm{v} / \mathrm{v}), \mathrm{P} 2 ; 15 \%$ (85: $15 \mathrm{v} / \mathrm{v})$ dan P3; 20\% (80: $20 \mathrm{v} / \mathrm{v})$. Hasil penelitian ini menunjukkan bahwa minuman whey fermentasi dengan penambahan sari kurma yang difermentasi dengan bakteri Lactobacillus fermentum B111 K (L. fermentum) selama 24 jam terbukti memiliki kemampuan antibakteri yang lebih tinggi pada level $20 \%$ dibandingkan dengan kontrol. yang tidak diberi jus kurma tambahan.
\end{abstract}

Kata kunci: bakteri asam laktat (BAL), antibakteri, L. fermentum, whey fermentasi, sari kurma

\section{PENDAHULUAN}

Whey merupakan produk sampingan utama (by-product) dari pembuatan keju yang masih kurang dimanfaatkan oleh industri pembuatan keju di Indonesia. Whey sangat berpotensi menyebabkan pencemaran lingkungan karena tingginya volume produksi yang dihasikan dan tingginya bahan organik yang terkandung dalam whey dengan kadar Chemical Oxigen Demand (COD) berkisar 60 000-80 000 ppm (Magalhães et al. 2010). Namun, whey masih mengandung beberapa nutrisi seperti laktosa, protein, lemak, asam laktat, dan sejumlah nutrien minor seperti laktoferin, laktoperoksidase, lisozim, immunoglobulin, zat besi, iodin, dan vitamin (De Witt 2001). Nutrisi tersebut berguna untuk kesehatan tubuh, oleh sebab itu salah satu cara pemanfaatan whey adalah dengan 
menjadikan whey sebagai produk minuman.

Whey yang dijadikan produk minuman perlu dikembangkan lagi supaya dapat meningkatkan nilai tambah whey. Salah satunya adalah dengan memfermentasikan whey melalui pemanfaatan bakteri asam laktat (BAL) untuk menghasilkan produk yang bernilai gizi tinggi dan bermanfaat untuk kesehatan. BAL yang digunakan dalam penelitian ini adalah Lactobacillus fermentum (L. fermentum) B111K. Penelitian Syah et al. (2017b) menunjukkan bahwa L. fermentum B111K yang diinokulasi dari dangke susu kerbau memiliki aktivitas daya hambat terhadap bakteri patogen, mampu bertahan terhadap $\mathrm{pH}$ rendah, dan garam empedu.

Optimalisasi proses fermentasi whey dengan bakteri L. fermentum B111K dapat dilakukan dengan penambahan substrat yang mendukung pertumbuhan BAL. Salah satu substrat yang dapat dimanfaatkan dengan mudah yaitu sari kurma. Sari kurma diharapkan dapat menjadi tambahan asupan nutrisi bagi BAL. Selain itu sari kurma memiliki kemampuan antibakteri yang baik sehingga diharapkan produk minuman whey fermentasi dengan penambahan sari kurma bermanfaat untuk kesehatan. Penelitian ini bertujuan untuk mengkaji kandungan kimiawi, total asam tertitrasi, $\mathrm{pH}$, total BAL dan kemampuan antibakteri pada produk minuman whey fermentasi dengan penambahan sari kurma (MFWSK).

\section{MATERI DAN METODE}

Bahan-bahan utama penelitian ini adalah whey keju mozzarella yang diperoleh dari PT. Tri Cheese, Sawangan, Depok. Lactobacillus fermentum B111K yang diperoleh dari koleksi bakteri di laboratorium Terpadu Fakultas Peternakan. Bakteri indikator yaitu Staphylococcus aureus ATCC 25923 dan enteropathogenic Escherichia coli ATCC 25923. Sari buah kurma dibuat dari kurma jenis deglet noor. Bahan-bahan lainnya yaitu deMann Rogosa Sharpe Agar (MRSA), Mueller Hinton Agar (MHA), 0.1\% fenoftalein, $0.1 \mathrm{NaOH}, 0.1 \mathrm{~N} \mathrm{HCL}$, dan $\mathrm{Na}_{2} \mathrm{CO}_{3}$.

\section{Pembuatan Sari Kurma}

Kurma sebanyak 250 gr yang telah dipilih dengan kualitas yang baik dipisahkan antara daging buah dengan bijinya kemudian dipotong kecil-kecil. Selanjutnya dihaluskan menggunakan blender dengan perbandingan kurma dan air (akuades) adalah 1:2 (kurma:air) w/v. Air digunakan sebagai pengencer sari kurma agar mudah digiling. Setelah dihaluskan ampas dan sari kurma dipisahkan melalui proses penyaringan dengan kain saring yang sudah disterilkan terlebih dahulu (Aljasass et al. 2010).

\section{Pembuatan Minuman Whey Fermentasi Sari Kurma (MWFSK)}

Whey yang diperoleh dari PT. Tri Cheese ditambahkan sari kurma sesuai dengan perbandingan whey dan sari kurma yang digunakan yaitu: 0\% sebagai kontrol (whey:sarikurma 100:0 v/v), 10\% (90:10 v/v), 15\% (85:15 $\mathrm{v} / \mathrm{v})$, dan 20\% (80:20 v/v). Whey dan sari kurma yang telah diformulasikan kemudian disterilisasi menggunakan autoclave (TOMY ES-315, Japan) pada suhu $115^{\circ} \mathrm{C}$ selama
3 menit. Setelah itu diturunkan suhunya hingga mencapai suhu $37{ }^{\circ} \mathrm{C}$. Whey kemudian diinokulasi dengan 5\% L. fermentum $\mathrm{B} 111 \mathrm{~K}$ dan difermentasi pada suhu $37^{\circ} \mathrm{C}$ selama 24 jam di dalam inkubator (Memmert Incubator Oven INB200, Germany) (Aljasass et al. 2010).

\section{Pengamatan Pertumbuhan BAL}

Minuman whey dengan penambahan sari kurma difermentasikan dan diukur pertumbuhannya setiap 4 jam sekali selama 32 jam untuk melihat kurva pertumbuhan BAL. Jumlah populasi BAL diukur menggunakan spektofotometer (Agilent 8453 UV-vis, US) dengan optical density $600 \mathrm{~nm}$ (OD600) (Modifikasi dari Todorov et al. 2012).

\section{Total Bakteri Asam Laktat}

Sampel sebanyak $25 \mathrm{~mL}$ dimasukkan ke dalam tabung reaksi berisi $225 \mathrm{~mL}$ larutan BPW. Selanjutnya Pengenceran 1 (P-1) diambil sebanyak $1 \mathrm{~mL}$ untuk dilarutkan ke dalam larutan pengencer BPW sebanyak $9 \mathrm{~mL}$ sehingga diperoleh P-2, demikian seterusnya dengan cara yang sama dilakukan hingga P-9. Pemupukan dilakukan dengan metode pour plate dimana sebanyak $1 \mathrm{~mL}$ sampel dari pengenceran P-6 sampai P-9 dipindahkan ke dalam cawan petri untuk kemudian dicampur dengan $15 \mathrm{~mL}$ media de man rogosa sharpe agar (MRSA). Cawan kemudian diinkubasi pada suhu $37^{\circ} \mathrm{C}$ selama 48 jam. Koloni BAL yang terbentuk kemudian dihitung dengan menggunakan metode standard plate count (SPC) (Pelezar dan Chan 2007).

\section{Pengujian Aktivitas Antibakteri BAL}

Pengujian aktivitas antimikroba dilakukan dengan menggunakan metode sumur difusi agar (well diffusion agar). Bakteri uji yang digunakan adalah Eschericia coli ATCC 25922 dan Staphylococcus aureus ATCC 25923. Masing-masing mikroorganisme tersebut diencerkan dalam media pengencer $\mathrm{NaCl}$ dan disetarakan dengan larutan 0.5 McFarland yang sebanding dengan populasi 108. Kemudian diencerkan sebanyak 2 kali ke dalam BPW 9 mL sehingga diperoleh populasi 106. Sebanyak $1 \mathrm{~mL}$ larutan BPW 106 dimasukan kedalam cawan petri, kemudian ditambahkan muller hinton agar (MHA) sebanyak $20 \mathrm{~mL}$. Setiap cawan mewakili satu bakteri. Lubang sumur dibentuk pada media agar yang telah mengeras menggunakan tabung Durham berdiameter $16 \mathrm{~mm}$ sebanyak 4 sumur setiap cawan. Sebanyak $300 \mu \mathrm{L}$ pada masing-masing sampel whey fermentasi sari kurma bebas sel dalam lubang sumur lalu didiamkan selama 3 jam dengan suhu $4{ }^{\circ} \mathrm{C}$ setelah itu di inkubasi pada suhu $37^{\circ} \mathrm{C}$ selama 24 jam. Diameter zona penghambatan diukur dengan menggunakan jangka sorong. Diameternya diukur sebanyak tiga kali ulangan di tempat yang berbeda dan hasilnya dirata-ratakan (Balouiri et al. 2017).

\section{Pengujian Sifat Kimiawi}

Pengujian kimiawi dilakukan setelah MFSK difermentasi dengan L. fermentum strain B111K. Pengujian kimiawi meliputi kadar air, protein, lemak, serat kasar, abu dengan analisis proksimat dianalisis berdasarkan metode AOAC (2005). 
Pengukuran kadar air diawali dengan menimbang sampel lalu dimasukkan ke dalam cawan porselen dan di oven pada suhu $105{ }^{\circ} \mathrm{C}$ selama 5 jam, kemudian cawan dimasukkan ke dalam desikator sampai dingin dan selanjutnya ditimbang kembali dan diambil datanya untuk dihitung.

Analisis protein terdiri atas tiga tahap, yaitu: destruksi, destilasi, dan titrasi. Pengukuran kadar protein dilakukan dengan metode mikro Kjeldahl. Sampel ditimbang sebanyak 0.25 gr, kemudian dimasukkan ke dalam labu Kjeldahl $100 \mathrm{~mL}$ dan ditambahkan satu butir kjeltab dan $3 \mathrm{~mL} \mathrm{H}_{2} \mathrm{SO}_{4}$ pekat. Sampel didestruksi pada suhu $410^{\circ} \mathrm{C}$ selama kurang lebih 1 jam sampai larutan jernih lalu didinginkan lalu dimasukkan ke dalam labu kjeldahl

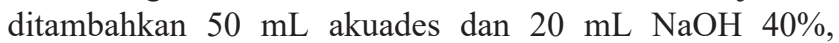
kemudian dilakukan proses destilasi dengan suhu destilator $100{ }^{\circ} \mathrm{C}$. Hasil destilasi ditampung dalam labu Erlenmeyer $125 \mathrm{~mL}$ yang berisi campuran $10 \mathrm{~mL}$ asam borat $\left(\mathrm{H}_{3} \mathrm{BO}_{3}\right)$ $2 \%$ dan tetes indikator bromcherosol green methyl red yang berwarna merah muda. Setelah volume destilat mencapai $40 \mathrm{~mL}$ dan berwarna hijau kebiruan, maka proses destilasi dihentikan. Lalu destilat dititrasi dengan $\mathrm{HCl} 0.1 \mathrm{~N}$ sampai terjadi perubahan warna merah muda.

Sampel diukur dengan melakukan refluks selama 6 jam. Pelarut lemak yang ada dalam labu lemak didestilasi hingga semua pelarut lemak menguap. Selanjutnya labu lemak dikeringkan dalam oven pada suhu $105^{\circ} \mathrm{C}$, setelah itu labu didinginkan dalam desikator sampai beratnya konstan.

Sampel dimasukkan ke dalam labu erlenmeyer dan ditambahkan $100 \mathrm{~mL}$ larutan $\mathrm{H}_{2} \mathrm{SO}_{4} 0.255 \mathrm{~N}$ mendidih lalu ditutup dan didiamkan selama 30 menit, selanjutnya ditambahkan $\mathrm{NaOH} 0.313 \mathrm{~N} 100 \mathrm{~mL}$ dan dipanaskan kembali selama 30 menit lalu didinginkan. Campuran kemudian disaring menggunakan kertas saring yang sudah diketahui bobotnya, sambil dicuci dengan $\mathrm{K}_{2} \mathrm{SO}_{4} \quad 10 \%$ lalu bilas dengan air panas, selanjutnya dibilas dengan alkohol 95\%. Kertas saring dikeringkan dengan oven selama 10 menit pada suhu $110{ }^{\circ} \mathrm{C}$ lalu ditimbang secara berulang sampai mencapai berat konstan.

Sampel ditimbang di dalam cawan porselen, lalu dimasukkan ke dalam tanur pengabuan dengan suhu $600{ }^{\circ} \mathrm{C}$ selama 1 jam, kemudian ditimbang sampai mencapai berat konstan.

\section{Nilai Total Asam Tertitrasi}

Total asam tertitrasi (TAT) dianalisis berdasarkan AOAC (2005) dengan metode titrasi $\mathrm{NaOH} 0.1 \mathrm{~N}$ dan phenolphtalein $1 \%$ sebagai indikator. Sampel sebanyak $10 \mathrm{~mL}$ dan ditambahkan 2 tetes $(300 \mu \mathrm{L})$ indikator phenolphtalein $1 \%$, kemudian dititrasi dengan $0.1 \mathrm{~N}$ larutan $\mathrm{NaOH}$ hingga muncul warna merah muda. Jumlah asam yang diproduksi selama fermentasi yang disertakan dengan asam laktat dapat dihutung dengan rumus sebagai berikut:

$$
\left[\text { Asam laktat }(\%)=\frac{m l ~ N a O H \times 0,1 \mathrm{~N} \times 90,08}{m L \text { sampel } \times 1000} \times 100 \%\right]
$$

\section{Nilai pH}

Pengukuran nilai $\mathrm{pH}$ dilakukan menggunakan alat pH meter (SCHOTT ${ }^{\circledR}$ Instruments Lab 850, Germany) yang telah dikalibrasi terlebih dahulu dengan buffer $\mathrm{pH} 7$ dan 4 . Pengukuran dilakukan dengan mencelupkan elektroda ke dalam sampel minuman whey fermentasi setelah terlebih dahulu elektroda dibersihkan dengan akuades (AOAC 2005).

Rancangan menggunakan rancangan acak kelompok (RAK) dengan penambahan sari kurma P1; 0\% (kontrol), P2; 10\%, P3; 15\%, P4; 20\%, dan setiap masing-masing perlakuan dibagi menjadi 6 kelompok. Data yang diperoleh dianalisis dengan ANOVA. Jika perlakuan berpengaruh nyata maka dilanjutkan dengan uji Tukey. Pengolahan data dilakukan dengan menggunakan program SAS versi 9.4 (Steel dan Torrie 1995).

\section{HASIL DAN PEMBAHASAN}

\section{Pertumbuhan Bakteri Asam Laktat}

Pertumbuhan BAL di dalam media whey perlu dikaji untuk mengetahui waktu inkubasi optimum yang akan mempengaruhi karakteristik produk fermentasi yang dihasilkan. Pertumbuhan BAL pada minuman whey fermentasi dengan penambahan sari kurma dapat dilihat pada Gambar 1 .

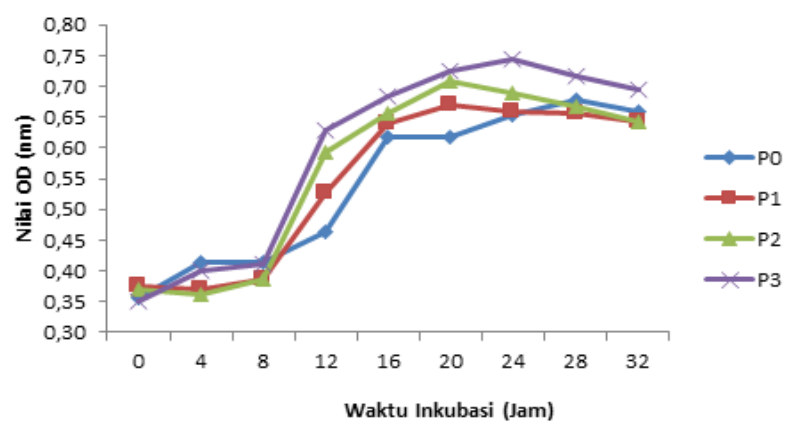

Gambar 1. Kurva pertumbuhan BAL pada minuman whey fermentasi dengan penambahan sari kurma selama 32 jam. $\mathrm{P} 0=$ sebagai kontrol (tanpa penambahan sari kurma), P1=penambahan sari kurma $10 \%, \mathrm{P} 2=$ penambahan sari kurma $15 \%$, P3=penambahan sari kurma 20\%

Gambar 1 kurva pertumbuhan BAL pada minuman whey fermentasi dengan penambahan sari kurma selama 32 jam. $\mathrm{P} 0=$ sebagai kontrol (tanpa penambahan sari kurma), $\mathrm{P} 1=$ penambahan sari kurma 10\%, P2=penambahan sari kurma 15\%, P3=penambahan sari kurma 20\%.

Gambar 1 menunjukkan bahwa populasi BAL pada setiap perlakuan umumnya meningkat seiring dengan lamanya waktu inkubasi, hingga pada waktu inkubasi 20 jam laju pertumbuhan bakteri asam laktat berbeda nyata $(\mathrm{P}<0.05)$ diantara perlakuan pada waktu inkubasi jam ke-8 hingga jam ke-20. Pertumbuhan BAL tertinggi pada inkubasi jam ke-8 diperoleh pada perlakuan $\mathrm{P} 0$ dengan nilai OD (optical dencity) $0.41 \mathrm{~nm}$, namun pada waktu inkubasi jam ke-12, 16, 20, 24, 28, dan 32 nilai tertinggi diperlihatkan 
pada perlakuan P3 dengan nilai OD berturut-turut 0.63 , $0.68,0.72,0.75,0.72$ dan $0.70 \mathrm{~nm}$. Berdasarkan kurva pertumbuhan BAL pada Gambar 1 menunjukkan bahwa penambahan sari kurma pada setiap perlakuan berdampak positif terhadap pertumbuhan BAL sehingga substrat antibakteri yang terdapat pada sari kurma tidak berdampak negatif terhadap pertumbuhan BAL. Adanya kandungan sukrosa pada sari kurma menyebabkan tingginya nilai OD pada perlakuan penambahan sari kurma dibandingkan dengan kontrol tanpa penambahan sari kurma. Syah et al. (2017b) menyatakan bahwa BAL mampu memanfaatkan sukrosa sebagai media pertumbuhannya.

Berdasarkan kurva pertumbuhan BAL pada Gambar 1. menunjukkan bahwa fase lag (adaptasi) BAL terjadi pada waktu inkubasi jam ke-0 hingga jam ke-8. Pada fase lag berlangsung cukup lama, hal ini terjadi karena BAL baru saja menyesuaikan diri terhadap media. Hasil dari penelitian ini sejalan dengan hasil penelitian yang dilakukan oleh Syah et al. (2017a) dan Puspawati et al. (2010) bahwa pertumbuhan BAL pada media whey fase lag yang terjadi pada jam ke 0 sampai jam ke 8 yang berlangsung cukup lama karena disebabkan BAL baru bisa beradaptasi dengan media yang baru.

Fase logaritmik dimulai dari jam ke- 8 hingga jam ke-20. Hal ini dapat terlihat dari pertumbuhan BAL yang meningkat secara signifikan. Menurut Yuliana (2012), BAL biasanya mencapai fase logaritmik pada waktu inkubasi jam ke-8 hingga jam ke-24, namun tergantung pada media dan strain bakteri. Fase stasioner BAL terjadi pada waktu inkubasi di atas jam ke-20, dimana pertumbuhan BAL relatif lebih lambat dan cenderung stabil dan konsentrasi biomassa menjadi maksimal (Puspawati et al. 2010). Pertumbuhan BAL sangat bergantung pada aktivitas metabolisme yang dipengaruhi oleh ketersediaan makanan di dalam media. Menurut Delgado-Fernández (2019) dan Ayad et al. (2020) ada beberapa faktor yang dapat mempengaruhi laju pertumbuhan BAL yaitu kurma yang mengandung fruktosa dan glukosa hanya terdiri dari dua pertiga dari daging kurma, sehingga lamanya waktu fermentasi dan jumlah substrat yang ditambahakan sangat mempengaruhi laju pertumbuhan BAL.

\section{Total BAL dan Aktivitas Antibakteri}

Pengujian Total BAL bertujuan mengetahui kemampuan hidup BAL pada proses produksi minuman whey fermentasi dengan penambahan sari kurma selama 24 jam. Populasi BAL dapat dilihat pada Tabel 1. Populasi BAL tiap perlakuan menunjukkan hasil yang tidak berbeda nyata $(\mathrm{P}>0.05)$, namun secara deskriptif menunjukkan bahwa populasi BAL semakin meningkat seiring dengan meningkatnya penambahan sari kurma. Total BAL yang tidak berbeda nyata diantara perlakuan menunjukkan bahwa sari kurma yang ditambahkan toleran terhadap BAL sehingga BAL dapat tumbuh secara optimal. Populasi BAL tertinggi ditunjukkan pada penambahan sari kurma 20\% yaitu sebesar $10.14 \log \mathrm{cfu} \mathrm{mL}^{-1}$, sedangkan populasi BAL terendah ditunjukkan pada $0 \%$ (kontrol) dengan nilai 9.49 $\log$ cfu $\mathrm{mL}^{-1}$. Hasil penelitian ini lebih tinggi dari pada hasil penelitian Syah et al. (2017b), Moslehishad et al. (2013)
Tabel 1. Total BAL dan diameter zona hambat terhadap $S$. aureus dan $E$. coli pada minuman whey fermentasi dengan penambahan sari kurma

\begin{tabular}{lccc}
\hline Perlakuan & Total BAL & $\begin{array}{c}\text { S. aureus } \\
\text { ATCC 25923 }\end{array}$ & $\begin{array}{c}\text { E. coli ATCC } \\
25922\end{array}$ \\
\cline { 2 - 4 } & $\left(\log \mathrm{cfu} \mathrm{mL} \mathrm{m}^{-1}\right)$ & $(\mathrm{mm})$ & $(\mathrm{mm})$ \\
\hline $0 \%$ & $9.49 \pm 0.07$ & $6.14 \pm 1.30 \mathrm{~b}$ & $3.11 \pm 2.30 \mathrm{~b}$ \\
$10 \%$ & $9.76 \pm 0.22$ & $7.12 \pm 1.21 \mathrm{ab}$ & $6.73 \pm 0.36 \mathrm{ab}$ \\
$15 \%$ & $9.92 \pm 0.71$ & $9.07 \pm 1.22 \mathrm{ab}$ & $9.43 \pm 2.10 \mathrm{a}$ \\
$20 \%$ & $10.14 \pm 1.16$ & $10.43 \pm 1.47 \mathrm{a}$ & $9.64 \pm 1.29 \mathrm{a}$ \\
\hline
\end{tabular}

Huruf yang berbeda di belakang angka pada kolom yang sama menunjukkan perbedaan nyata $(\mathrm{P}<0.05)$

dan Zhang et al. (2011) yaitu berkisar antara 7.28 - 8.90 $\log \mathrm{cfu} \mathrm{mL}^{-1}$. Penelitian ini sejalan dengan hasil penelitian Febrisiantosa et al. (2013) yang melaporkan bahwa populasi BAL berkisar antara $9.67-11.20 \log$ cfu $\mathrm{mL}^{-1}$.

Jumlah Populasi BAL pada semua perlakuan telah memenuhi syarat ambang batas minimum yang telah disyaratkan oleh CODEX STAN 234-2003 yaitu minimal 7 $\log \mathrm{cfu} \mathrm{mL}^{-1}$. Populasi BAL yang tinggi diduga disebabkan oleh kondisi lingkungan dan nutrisi didalam media fermentasi yang baik untuk pertumbuahan BAL. Aktivitas metabolisme BAL bergantung pada kandungan gula yang dibutuhkan oleh BAL seperti glukosa, fruktosa dan sukrosa. Hal ini didukung oleh Hastuti (2020) bahwa proses fermentasi BAL pada umumnya memanfaatkan karbohidrat seperti glukosa, fruktosa dan sukrosa sebagai sumber nutrisi utama.

Aktivitas antibakteri dapat diketahui dari diameter zona hambat yang terbentuk. Bakteri patogen yang digunakan yaitu S. aureus ATCC 25923 (Gram positif) dan $E$. coli ATCC 25922 (Gram negatif), dengan populasi bakteri masing-masing yaitu $2.04 \times 108$ dan $2.5 \times 107 \mathrm{cfu}$ $\mathrm{mL}^{-1}$. Hasil dari pengujian aktivitas antibakteri dengan bakteri uji (S. aureus ATCC 25923 dan E. coli ATCC 25922) menunjukkan bahwa perlakuan penambahan sari kurma memiliki kemampuan antibakteri yang dapat menghambat bakteri patogen uji secara signifikan $(\mathrm{P}<0.05)$ baik pada bakteri gram positif ( $S$. aureus ATCC 25923) maupun gram negatif ( $E$. coli ATCC 25922) yang ditunjukkan pada diameter zona hambat pada Gambar 2. Semakin tinggi konsentrasi penambahan sari kurma menunjukkan bahwa diameter zona hambat yang terbentuk semakin besar, seperti yang terlihat pada Gambar 2. Daya hambat bakteri tertinggi ditunjukkan oleh P3 (penambahan sari kurma 20\%) pada bakteri S. aureus ATCC 25923 dan E. coli ATCC 25922 dengan besaran diameter zona hambat berturut-turut yaitu $10.43 \mathrm{~mm}$ dan $9.64 \mathrm{~mm}$.

Perlakuan kontrol tanpa penambahan sari kurma tetap memiliki aktivitas antibakteri karena menurut Das et al. (2013) menyatakan bahwa supernatan tanpa sel yang dihasilkan dari Lactobasillus adalah suatu senyawa yang mengandung beberapa antimikroba sehingga mampu menghambat mikroorganisme patogen, yaitu asam laktat dan hidrogen peroksida. Bao et al. (2010) juga melaporkan BAL dapat menghasilkan asam laktat, $\mathrm{CO}_{2}$, etanol dan senyawa volatil seperti diasetil, dari hasil proses fermentasi 
(a)

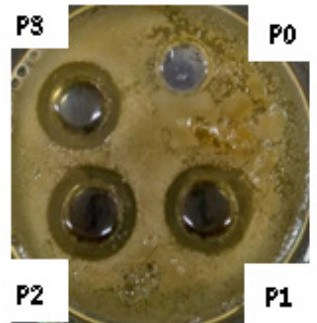

(b)

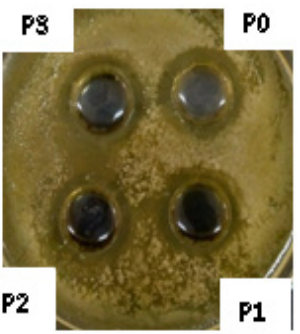

Gambar 2. Zona hambat isolat BAL L. fermentum B111K terhadap bakteri patogen. (a) bakteri E. coli ATCC 25923, (b) S. aureus ATCC 25922

yang terakumulasi. Perlakuan penambahan sari kurma memiliki diameter zona hambat yang lebih besar karena sari kurma memiliki substrat antibakteri. Menurut Sani et al. (2017), kurma memiliki aktivitas antibakteri karena adanya saponin dan flavonoid yang mampu membentuk pori-pori pada membran sehingga memberikan efek bakterisidal.

\section{Komposisi Kimiawi, Nilai Total Asam Tertitrasi, dan pH}

Pengujian komposisi kimiawi pada minuman whey fermentasi dengan penambahan sari kurma (Tabel 2) tidak menunjukkan adanya perbedaan nyata diantara perlakuan terhadap semua nilai peubah yang diuji. Peningkatan konsentrasi penambahan sari kurma pada minuman whey fermentasi menyebabkan meningkatnya kadar abu dan serat kasar diiringi dengan menurunnya kadar air, lemak, dan protein. Hal ini sejalan dengan penelitian Syah et al. (2017a) yang menyatakan bahwa whey dengan penambahan sukrosa akan meningkatkan kadar abu, karbohidrat dan penurunan kadar air dan kadar protein dibandingkan dengan whey tanpa penambahan sukrosa.

terkandung dalam minuman whey fermentasi dengan penambahan sari kurma. Menurut Ni dan Raikos (2019) menyatakan bahwa selama fermentasi BAL memproduksi asam laktat dan asam asetat dari aktivitas metabolisme dan menurunkan $\mathrm{pH}$ secara bertahap.

Menurut M'hir et al. (2019) pH merupakan faktor penting yang sangat mempengaruhi kualitas produk fermentasi, oleh karena itu perlu adanya pengukuran $\mathrm{pH}$. Hasil uji $\mathrm{pH}$ menunjukkan adanya perbedaan nyata $(\mathrm{P}<0.05)$ terhadap perlakuan (Tabel 2). Penambahan sari kurma menyebabkan turunnya nilai $\mathrm{pH}$. Hal ini diakibatkan oleh adanya aktiviitas metabolime BAL yang merubah kandungan gula yang terdapat pada media menjadi asamasam organik. Beux et al. (2020) menyatakan bahwa penurunan $\mathrm{pH}$ diakibatkan dari hasil proses fermentasi yang melibatkan aktivitas metabolisme BAL sehingga substrat yang terkandung dalam media berubah menjadi asam-asam organik seperti asam laktat dan asam asetat. Gänzle (2015) juga menyatakan bahwa produk utama dari metabolisme BAL adalah asam-asam organik yang bergantung pada waktu fermentasi, komposisi kultur dan sebagian besar aktivitas metabolisme BAL yang ditentukan pada ketersediaan makanan yang difermentasikan.

\section{KESIMPULAN}

Produk minuman whey fermentasi dengan penambahan sari kurma pada taraf $20 \%$ yang difermentasikan dengan bakteri L. fermentum B111K selama 24 jam telah terbukti memiliki kemampuan antibakteri terhadap $E$. coli ATCC 25923 dan S. aureus ATCC 25922 yang lebih tinggi dibandingkan dengan kontrol yang tidak diberikan penambahan sari kurma.

Tabel 2. Hasil uji kimiawi, TAT, dan $\mathrm{pH}$ pada minuman whey fermentasi dengan penambahan sari kurma

\begin{tabular}{lcccc}
\hline \multicolumn{1}{c}{ Peubah } & \multicolumn{1}{c}{$0 \%$} & \multicolumn{1}{c}{$10 \%$} & $15 \%$ & $20 \%$ \\
\hline Kadar Air (\%) & $96.07 \pm 4.30$ & $91.53 \pm 0.07$ & $90.31 \pm 0.04$ & $89.06 \pm 0.04$ \\
Kadar Abu (\%) & $0.21 \pm 0.27$ & $0.39 \pm 0.10$ & $0.43 \pm 0.05$ & $0.63 \pm 0.03$ \\
Lemak (\%) & $0.27 \pm 0.03$ & $0.26 \pm 0.01$ & $0.22 \pm 0.02$ & $0.22 \pm 0.08$ \\
Protein (\%) & $1.77 \pm 0.16$ & $1.50 \pm 0.68$ & $1.16 \pm 0.04$ & $1.09 \pm 0.06$ \\
Serat Kasar (\%) & $0.01 \pm 0.00$ & $0.02 \pm 0.00$ & $0.02 \pm 0.01$ & $0.02 \pm 0.00$ \\
TAT (\%) & $1.75 \pm 0.06 \mathrm{~d}$ & $2.10 \pm 0.03 \mathrm{c}$ & $2.23 \pm 0.08 \mathrm{~b}$ & $2.36 \pm 0.04 \mathrm{a}$ \\
pH & $4.10 \pm 0.01 \mathrm{a}$ & $3.98 \pm 0.01 \mathrm{~b}$ & $3.97 \pm 0.01 \mathrm{~b}$ & $3.98 \pm 0.01 \mathrm{~b}$ \\
\hline
\end{tabular}

Huruf yang berbeda di belakang angka pada baris yang sama menunjukkan perbedaan nyata $(\mathrm{P}<0.05)$

Berdasarkan hasil uji TAT menunjukkan adanya hasil yang berbeda nyata $(\mathrm{P}<0.05)$ akibat perlakuan penambahan sari kurma (Tabel 2). Semakin tinggi penambahan sari kurma maka semakin besar nilai TAT yang diperoleh. Nilai TAT tertinggi diperoleh pada penambahan sari kurma $20 \%$ yaitu $2.36 \%$ sedangkan nilai terendah ditunjukkan pada kontrol dengan nilai $1.75 \%$. Nilai total asam yang terhitung adalah hasil dari metabolisme dari BAL Lactobasillus fermentum B111K yang memanfaatkan semua sumber nutrisi yang

\section{DAFTAR PUSTAKA}

Aljasass, F. M., S. M. Aleid, \& A. A. El-Neshwy. 2010. Utilization of Dates In The Manufacture of New Probiotic Dairy Food. First Annual Report. Date Palm Research Center. King Faisal University. Al-Ahsa. Project No. PR3.

AOAC. 2005. Official Methods of Analysis of AOAC International. Di dalam: Howitz W, et al. editor. Dairy 
Products. Gaithersburg, Maryland (USA):AOAC International. 33:1-15.

Balouiri, M., M. Sadiki, \& S. K. Ibnsouda. 2016. Methode For In Vitro Evaluating Antimicrobial Activty: A Review. Journal of Pharmaceutical Analysis. 6(2):7179.

Bao, Y., Y. Zhang, Y. Zhang, Y. Liu, S. Wang, X. Dong, \& H. Zhang. 2010. Screening of Potential Probiotic Properties of Lactobacillus fermentum Isolated From Traditional Dairy Products. Food Control. 21(5):695701.

Beux, S., C. Todescatto, J. F. Marchi, \& E. A. Pereira. 2020. Selection of Raw Cow's Milk Thermophilic Lactic Acid Bacteria Obtained From Southwest Parana, Brazil With Potential Use as Autochthonous Starter. Brazilian Journal of Food Technology. 23:1981-6723.

De Witt, J. N. 2001. Lecture's Handbook on Whey and Whey Product. European Whey Products Association. Brussels. Belgium.

Das, J. K., D. Mishra, P. Ray, P. Tripathy, T. K. Beuria, N. Singh, \& M. Suar. 2013. In Vitro Evaluation of Anti-Infective Activity of a Lactobacillus plantarum Strain Against Salmonella enterica serovar enteritidis. Gut Pathogens. 5(1):11.

Delgado-Fernández, P., N. Corzo, A. Olano, O. Hernández-Hernández, \& F. J. Moreno. 2019. Effect of Selected Prebiotics on The Growth of Lactic Acid Bacteria and Physicochemical Properties of Yoghurts. International Dairy Journal. 89:77-85.

Febrisiantosa, A., B. P. Purwanto, Y. Widyastuti, I. I. Arief. 2013. Physical, Chemical and Microbiological Characteristics of Whey Kefir and Its Angiotensin Converting Enzyme (ACE) Inhibitory Act. Jurnal Teknologi dan Industri Pangan. 24(2):147-147.

Gänzle, M. G. 2015. Lactic Metabolism Revisited: Metabolism of Lactic Acid Bacteria In Food Fermentations and Food Spoilage. Current Opinion in Food Science. 2:106-117.

Hastuti, L. I. 2020. Kemampuan Fermentasi BAL dengan Substrat Susu Kacang Merah. Bioeksperimen: Jurnal Penelitian Biologi. 6(2):116-122.

Liévin-Le Moal, V., \& A. L. Servin. 2014. Antiinfective Activities of Lactobacillus Strains In The Human Intestinal Microbiota: from Probiotics To Gastrointestinal Anti-infectious Biotherapeutic Agents. Clinical microbiology reviews. 27(2):167-199.

M'hir, S., K. Rtibi, A. Mejri, M. Ziadi, H. Aloui, M. Hamdi, \& L. Ayed. 2019. Development of a Novel Whey Date Beverage Fermented with Kefir Grains Using Response Surface Methodology. Journal of Chemistry. 2019.
Magalhães, K. T., M. A. Pereira, A. Nicolau, G. Dragone, L. Domingues, J. A. Teixeira, J. B. de Almeida Silva, \& R. F. Schwan. 2010. Production of Fermented Cheese Whey-Based Beverage Using Kefir Grains as Starter Culture: Evaluation of Morphological and Microbial Variations. Bioresour Technol. 101(22):8843-8850.

Masmoudi, M., S. Besbes, C. Blecker, \& H. Attia. 2010. Preparation and Characterization of Jellies with Reduced Sugar Content From Date (Phoenix dactylifera L) and Lemon (Citrus limon L) By-products. Fruits. 65(1):21-29.

Ni, H., \& Raikos, V. 2019. Lactic-acid Bacteria Fermentation-Induced Effects on Microstructure and Interfacial Properties of Oil-In-Water Emulsions Stabilized By Goat-Milk Proteins. Lwt. 109:70-76.

Puspawati, N. N., L. Nuraida, \& D. R. Adawiyah. 2010. Utilization of Various Cryogenic Agents During Freeze Drying to Maintain The Viability of Lactic. Jurnal Teknologi dan Industri Pangan. 21(1):59-59.

Sani, N. M., F. Abdulkadir, \& N. S. Mujahid. 2017. Antimicrobial Activity of Phoenix dactylifera (date palm) on Some Selected Members of Enterobacteriaceae. Bayero Journal of Pure and Applied Sciences. 10(1):36-39.

SC (Codex Standard). 2011. Codex Standard for Fermented Milks: Codex Stan 243-2003. FAO United Nations: Roma.

Steel, R. G. D., \& J. H. Torrie. 1995. Prinsip dan Prosedur Statistika Suatu Pendekatan Biometri Ed ke-1. Terjemahan Bambang S, Jalarta (ID): PT Gramedia Pustaka Utama.

Syah S. P., C. Sumantri, I. I. Arief, \& E. Taufik. 2017 a. Karakteristik Minuman yang Difermentasikan Dengan Bakteri Asam Laktat Indigenus Asal Dangke. J. Tekn. 28(2):129-138.

Syah, S. P., C. Sumantri, I. I. Arief, \& E. Taufik. 2017 b. Strainion and Identification of Indigenous Lactic Acid Bacteria by Sequencing the 16S rRNA from Dangke, a Traditional Cheese from Enrekang, South Sulawesi. Pakistan J of Nutrition. 16(5):384-392.

Yuliana, N. 2012. Pengolahan Durian (Durio zibethinus) Fermentasi (tempoyak). Jurnal Teknologi \& Industri Hasil Pertanian. 12(2):74-80. 